Article

\title{
The Determinants of ESG Rating in the Financial Industry: The Same Old Story or a Different Tale?
}

\author{
Fabrizio Crespi ${ }^{1}$ and Milena Migliavacca ${ }^{2, *}$ (i) \\ 1 Department of Economics and Business, Università di Cagliari, Via Sant'Ignazio, 17, 09123 Cagliari, Italy; \\ fcrespi@unica.it \\ 2 Department of Economics and Business Administration, Università Cattolica del Sacro Cuore, \\ Largo A. Gemelli, 1, 20123 Milano, Italy \\ * Correspondence: milena.migliavacca@unicatt.it
}

Received: 2 July 2020; Accepted: 6 August 2020; Published: 8 August 2020

\begin{abstract}
Corporate social performance (CSP) and, in particular, environmental, social and governance (ESG) ratings became a focal point for scholars, practitioners and policy makers over the last decade. In order to better understand the dynamics underlying CSP within the financial industry, we investigate its determinants. Adding to the debate regarding CSP antecedents, we draw on a world-wide sample of 727 financial firms operating in twenty-two countries within the period 2006-2017 and look for firm, country and temporal factors that affect CSP. The main results of our empirical analyses provide evidence that financial firms' ESG scores are growing on a linear trend over time, and such tendency is enhanced by their size and profitability, together with the economic and social development of the country within which they operate. Our findings also show that the environmental, social and governance pillars follow independent patterns.
\end{abstract}

Keywords: ESG criteria; corporate social performance; social and environmental sustainability

\section{Introduction}

In recent years, we experienced an increase in public awareness towards the relevance of environmental and social well-being together with the role that companies play in these regards. This has led to increased expectations on the environmentally-friendly and socially responsible activities that companies are required to undertake. Practices such as the triple bottom line have since then become more and more widespread to ensure companies' coherence between corporate operations and environmental, social and governance (ESG) values and the current trend is set to put corporate financial performance (CFP) and corporate social performance (CSP) on a par.

With the growing public interest in the social, environmental and ethical profile of businesses, the financial industry is particularly under scrutiny; it is well-known that financial intermediaries play a crucial role in the transmission and allocation of financial resources and therefore, financial firms and especially banks, are subject to special legislation on capital adequacy (e.g., Basel III), resolution mechanisms (e.g., Bank Resolution and recovery directive, BRRD) and transparency (e.g., MiFID II). Nevertheless, a substantial number of scandals and crises hit the financial industry in the last decades [1,2].

The numerous latest financial scandals and crises clash with the prevailing tendency to value virtuous triple bottom lines [3]. Therefore, the current sustainability trend may be a turning point for financial firms to restore their credibility and reputation in the public opinions' eyes [4].

In effect, in response to the widespread decline in public trust and increased demand for transparency from investors, financial firms became more and more reactive to environmental, social 
and governance issues, so much so that the "sustainable finance rating addiction" became a widely recognized phenomenon in the industry [5].

In parallel, a rich body of academic works began to explore the relationship between CSP and a wide array of possible determinants, particularly resorting to cross-industry studies. The analogous efforts focused on the financial/banking industry are more fragmented and therefore lead to heterogeneous results. Two main strands of literature can be distinguished in this regard: On the one hand, some studies try to discover the determinants of CSP, ESG ratings and/or CSR disclosure. Hossain and Reaz [6], for instance, analyze a sample of 38 listed banks in India and discovered that a firm's size and assets-in-place were significantly positive towards CSR disclosure. Khan [7] focuses on the effect of corporate governance characteristics (such as non-executive directors and number of women on the board) on CSR reporting using a sample of private commercial banks operating in Bangladesh. Along the same lines, Bhasin et al. [8] investigate voluntary disclosure in the banking sector in Kazakhstan, whilst a recent study by Birindelli et al. [9] expands the analysis of board director characteristics and its effects on ESG performance to a sample of 108 listed banks in Europe and United States. Considering only the Islamic finance world, a study by El-Halaby and Hussainey [10] assesses the role of accounting standard on CSR disclosure, whilst Paltrinieri and co-authors [11] employ the Islamic Finance Development Indicator to explain banks' ESG scores.

On the other hand, looking at the dynamic between banks' financial characteristics and their CSP from almost an inverse perspective, several academic articles focus on the influence of CSP on CFP. Buallay [12] investigates the relationship between ESG and bank's operational (Return on Assets), financial (Return on Equity) and market performance (Tobin's Q) using a sample of 235 banks over a ten-year period. Shakil et al. [13] explore the effects of environmental, social and governance performance on financial performance on a sample of banks operating in emerging markets. Finally, Miralles-Quirós et al. [4], focus on the effect of CPS on banks' value creation between 2010 and 2015.

Despite these meaningful efforts, to the best of our knowledge, the literature lacks a comprehensive study that employs a multilevel framework of possible determinants on an international sample of financial firms.

This paper aims to enrich the broad strategic management and social issues literature and, in particular, the strand on CSP within the financial industry. To do so, we analyze an international sample of 727 financial firms, both banks and non-bank institutions (i.e., asset management, trading companies, financial products distributors, diversified financial services and consumer finance companies). We jointly consider all the typologies of possible antecedents reviewed in the extant literature: firm, country and temporal factors. We control for companies' size, risk, profitability and capitalization together with country-specific variables such as the legal framework and the economic and social development. To better capture the time effect on CSP and being able to evaluate the trends both in crisis and non-crisis periods, we set our analysis to cover the period 2006-2017. To preview the empirical results, we provide evidence that financial firms' CSPs are growing on a linear trend over time, and such tendency is enhanced by their size and profitability, together with the economic and social development of the country within which they operate. Our findings also show that the environmental (ENV) and social (SOC) pillars follow deeply heterogeneous patterns compared to the governance (GOV) pillar. Our study contributes to the existing academic debate on CSP, providing a comprehensive analysis on the causal relationship between firm, country, temporal factors and CSP in the financial industry, but also provides useful insight to policy makers and regulators, who should be aware that within the overall CSP scores, there are at least two competing forces at play. Moreover, our paper is timely, because, it provides empirical evidence that while designing a broad regulatory framework on sustainability, like the one under study in the European Union, regulators should ideally bear in mind that some basic financial fundamentals have a significant impact on a financial firms' ability to reach certain levels of CSP.

The remainder of the paper proceeds as follows. Section 2 provides an overview of the relevant literature; Section 3 illustrates the sample and the methodology employed, whereas the main results, 
the robustness checks and a further analysis are presented in Section 4 . Section 5 discusses the empirical results and Section 6 provides some concluding remarks.

\section{Literature Review}

The importance of CSP has been widely investigated by scholars. The seminal studies date back to the 1990s and were mainly focused on the reasons why companies should engage in costly CSR activities and develop CSR disclosure [14]. The extant literature revolves around two theoretical frameworks [15]: the institutional theory, which indicates that organizations are influenced by broader economic and social structures, such as laws, public and private regulations, and the presence of international, non-governmental authorities that monitor corporate behaviors affecting firms' activities, business model and strategies [16]. This is particularly true for the financial industry, which has always been heavily regulated ex-ante due to its social function and ex-post as a consequence of the severe crises and scandals it experienced. The legitimacy theory, on the other hand, points out the importance of reputation, corporate image and societal acceptance in ensuring a company's success.

Starting from the end of the last century, and then much more in the aftermath of the global financial crisis, the wide adoption of ESG ratings contributed to a relevant increase in the academic research on the topic with a spike after the publication of the United Principles for Responsible Investment (PRI) [17]. The topic lends itself to different declinations, which result in a wide array of heterogeneous strands of academic literature. Herein follows a brief overview.

Traditionally, research in strategic management has explored the effect of firm, industry, country and time factors on firms' corporate financial performance; more recently, such a research framework has been adapted to corporate social disclosure and marginally to corporate social performance (e.g., $[15,18,19])$.

This strand of literature is particularly rich but provides a heterogeneous array of results; this might be due to the different metrics used to measure CSP, the prevailing national setting of the studies and the different timeframes analyzed. Moreover, most studies only employ firm-specific variables as possible CSP determinants. Furthermore, some contributions focus exclusively on corporate social disclosure, rather than performance, or even posit an inverted causal relationship between CSP and financial fundamentals, as briefly summarized below.

As mentioned, one reason underlying the mixed evidence on CSP has been the lack of a common, broadly accepted definition of sustainability, and therefore, the lack of a standardized measurement scale. In the early stages, CSP research has, for the most part, been based on ratings and checklists developed by individual researchers who manually collected the data from annual reports or corporate websites. More recently, ESG ratings coming from specialized information providers have become the standard indicators in academic research; we resort to MSCI ESG Research scores to measure financial firms' CSP, because of its granular coverage and due to comparability reasons, as it has been actively used in recent contributions relevant to this study. Still, there is an ongoing debate over the stability and effectiveness of ESG indicators. Doyle [17], for instance, points out that individual agencies' ESG ratings can vary dramatically, so that a company can be simultaneously assigned vastly divergent ratings by different agencies, due to difference in methodology, assessment strategies and subjective interpretations of soft information. There are also inherent biases: from market capitalization to geographical setting, industry or sector-all rooted in a lack of uniform disclosure. Other comparable studies are Berg et al. [20] and Escrig-Olmedo et al. [3]; the former documents that $53 \%$ of the difference of the ratings stems from measurement divergence, while scope divergence explains $44 \%$, and weight divergence another 3\%. The latter investigates how the criteria used by ESG rating agencies evolve over time and shows that ESG rating agencies do not fully integrate sustainability principles into the corporate sustainability assessment process.

It is also worth underlining that several studies point out that CSR activities and CSP should be disclosed externally with a certain intensity in order to exert their positive effect; therefore, CSP and corporate social disclosure are closely related and interdependent. In a study dedicated to the 
consequences of mandatory corporate sustainability reporting, Ioannou and Serafeim [21] indicate that the form and intensity of CSP reporting differ widely across firms. It can be argued that a firm's ESG engagement is a predictor of its ESG reporting practices: Firms with a positive CSP would choose to report extensively on their ESG activities, and those with a negative ESG performance would choose to report minimally. According to this framework, firms signal their ESG performance to distinguish themselves from poorer performers and thus avoid the consequences of adverse selection. However, a firm could also choose to report more or less information on CSP for other reasons: For instance, an acute environmental damage that impacts negatively the firm's reputation could force it to increase CSR and ESG disclosure. Companies could also use disclosure irrespectively of their true ESG performance (greenwashing) [22] or, inversely, managers could choose not to publicize their environmentally or socially responsible investments if they fear that investors may perceive these activities as unnecessary costs detrimental to their interests (brownwashing) [23].

As aforementioned, the studies focusing on CSP determinants tend to be fragmented, even because four possible categories of antecedents (firm, country, industry and temporal factors) have been alternatively employed to explain a firm's CSP. Looking specifically to firm-related characteristics, two relevant literature reviews by Elsakit and Worthington [24] and Giannarakis [25] present an in-depth analysis of the determinants of CSR disclosure. The most relevant explanatory variables are firm size (e.g., Rahman et al. [26], Jennifer-Ho and Taylor [27], Khan [7], Hossain [6]), profitability (e.g., Haniffa and Cooke [28]), leverage, board characteristics (size, women on board, board's average age), visibility and media exposure (e.g., Reverte [29]). From an industry-level perspective, the studies point out that financial and healthcare industry are shown to be the most transparent with regard to their CSR practices, whilst consumer's staples and information technology are negatively related to sustainability disclosure. In a more comprehensive study, Baldini et al. [15] analyze the impact of temporal, country and firm-level variables in an international cross-industry sample. The results of this study indicate that structural country factors significantly affect firms' ESG disclosure, suggesting that the political, labor, and cultural systems play an important role, as claimed by institutional theory. Additionally, all firm-specific variables related to a company's visibility have a positive and significant impact on overall ESG disclosure, as well as on its three pillars. Moura-Leite et al. [19], for instance, analyze a sample of 495 US firms from 19 industries over a five-year period. The study aims to explore the relative importance of industry and firm-level factors on CSP. The results of this study show a large firm-level effect on CSR (58\% of the variance in the composite measure). Nonetheless, CSR records a percentage of variance estimates within industry-levels (14\%) that was considerably higher compared to CFP. Short et al. [18] analyze a sample of 617 US firms operating in 158 industries over a nine-year period, using the Kinder, Lydenberg and Domini Co. (KLD) database to examine the degree to which CSP is related to firm, industry, and temporal factors. The results show that the effect of firm-level factors ranged from 27 to $65 \%$ of the variance in CSP, whereas the variance at the industry-level was significant for 10 out of 12 possible dimensions of CSP; overall, the analysis provides evidence that CSP tends to change in a linear manner over time, however, its slope changes across firms and industries.

Finally, another wide strand of research looks at the topic from almost an opposite perspective and specifically investigates the impact of CSR performance and CSR disclosure on firm value. In their overview, Fatemi et al. [30] find that research results are far from being homogeneous: In early contributions, the costs required to implement environmentally or socially responsible activities above the legally binding minimum standards would reduce firm value. Instead, more recent contributions to the field recognize ESG activities as having the potential to increase firm value (e.g., [4,31,32]). One of the most detailed meta-analysis on the topic (i.e., Margolis et al. [33]) highlights an overall positive effect, though small and possibly decreasing over time.

Even when we narrow the analysis to the financial sector, the literature does not reach a consensus on the relationship between financial fundamentals and firms' CSP. Only few studies focus directly on the financial sector, and even fewer present a cross-country analysis; moreover, the same geographical, temporal and methodological limitations that affect the wider cross-industry literature are also present 
in this strand. As aforementioned, the streams of literature dealing with companies' corporate social performance and corporate social disclosure are deeply interconnected, and overall, four possible categories of antecedents have been identified combining those research fields: firm, country, industry and temporal factors.

Khan [7] investigates the effects of corporate governance elements on CSR reporting in Bangladesh's banking sector. The results of the study provide evidence that non-executive directors influence CSR disclosure, while the presence of women on the board is not statistically significant. Size and profitability are statistically strong drivers, supporting the idea that larger companies make more CSR reporting because of accountability and visibility, in line with the legitimacy theory principles.

In a similar analysis, Bhasin et al. [8] investigate the extent and determinants of total voluntary disclosure and disclosure categories in financial and non-financial reports of banking companies listed on the Kazakhstan Stock Exchange (39 institutions). The study mainly focuses on the association between voluntary disclosure and governance factors, such as board size and board composition. The empirical results suggest that the number of outside directors is the most significant determinant of disclosure. The empirical analysis also points out that an increase in bank size leads to higher degree of voluntary reporting, as well; however, the findings provide evidence that voluntary reporting does not improve over time. Along the same lines, Forte et al. [34] focus on the voluntary disclosure degree of the 100 largest Brazilians banks. The authors posit that the volume of voluntary disclosure is positively affected by companies' reputation and size.

Focusing on corporate governance, the work by Birindelli et al. [9] is based on a sample of 108 listed banks in Europe and the United States for the period 2011-2016. The empirical results show that banks' CSP is positively associated with women on the board of directors, board size, the presence of a CSR committee and bank size. A cross-country analysis presented by El-Halaby and Hussainey [10] investigates the determinants of corporate social responsibility disclosure (CSRD) of Islamic banks around the world. The sample is composed of 138 institutions across 25 countries. The analyses show that the use of accounting standards and the presence of auditors are positively associated with CSRD. Once again, size plays an important role in determining the magnitude of CSRD, whilst a bank's profitability (ROA) is insignificant. As in Bhasin et al. [8], the age of the bank is not associated with higher levels of disclosure, similarly to the proxy for risk (Tier 1 capital), which does not seem to play a significant role in CSRD determination.

Lastly, Ng [35] investigates what drives sustainability disclosure in the emerging economies. This study, based on a sample of 251 banks from 45 emerging countries over the period 2005-2014, tries to explain ESG sustainability using tangible factors such as banks' fundamentals, country ESG performance, macroeconomic variables and institutional quality. The results show that size, liquidity, years of establishment and market power positively influence banks' disclosure of ESG policies and practices.

Over and above these considerations, as aforementioned, even the causal direction between financial firms' fundamentals and their CSP is still under debate in the literature. A relevant recent study [4], investigates how ESG performance influences shareholder value creation (measured as Tobin's Q). Based on a sample of 166 commercial banks listed in 31 stock markets from 2010 to 2015; the study provides evidence of a positive and significant relationship between banks' CSP and Tobin's $Q$ and, therefore, on shareholder value creation. In contrast, the social performance dimension results are negatively related to shareholder value creation. In a similar study, Shakil et al. [13] focus on 93 banks operating in emerging countries in the period 2015-2018. In this case, the authors find that environmental performance and social performance have a positive influence on financial performance (measured as ROA and ROE), whilst governance performance does not influence the financial performance. Similarly, Buallay [12] investigates the relationship between the ESG scores of 235 European banks and their operational, financial and market performance. Even if the global ESG disclosure is positively correlated to the three measures of performance used in the analysis, a separate analysis on the three ESG pillars shows that environmental disclosure has, indeed, a positive 
influence on financial and market performance, whilst corporate social responsibility has a negative relationship with the three performance indicators. Finally, according to the authors, the corporate governance disclosure negatively affects the financial and operational performance but disclosing more information about the governance practices may positively affect the Tobin's $Q$.

Drawing on this rich but fragmented literature, we posit that a comprehensive analysis of CSP determinants in the financial industry should include firm, country and temporal factors. Thus, connecting institutional and legitimacy theories, we develop our hypotheses and model how financial firms' characteristics, together with institutional structures and time trends jointly impact CSP.

\section{Methodology}

The main goal of this paper is to look at the determinants of CSP within the financial industry. To do so, we rely on both institutional and legitimacy theories and build on the previous literature to test a comprehensive set of hypotheses that include all three categories of antecedents, which have been identified but never jointly tested before within the financial industry, to the best of our knowledge.

Drawing from the legitimacy theory, we hypothesize that firm-level factors play a relevant role in financial firms' CSP and, in particular, we posit the following hypotheses:

H1a. The size of financial firms has a positive impact on their CSP.

H1b. The riskiness of financial firms has a negative impact on their CSP.

H1c. The capitalization degree of financial firms has a positive impact on their CSP.

H1d. The profitability of financial firms has a positive impact on their CSP.

The institutional theory, on the other hand, maintains that organizations are influenced by broader social and economic factors, therefore we hypothesize as follows:

H2a. The legal framework of the country in which a financial firm operates influences its CSP.

H2b. The higher the economic development of the country in which a financial firm operates, the higher its CSP.

H2c. The higher the social development of the country in which a financial firm operates, the higher its CSP.

Finally, we model time itself as a possible antecedent of financial firms' CSP:

H3. There is a significant positive trend in financial firms' CSP.

To test this set of hypotheses, we use an unbalanced panel of annual data of 727 financial firms, from twenty-two countries covering the period 2006-2017. The countries included in the sample and their relative presence within the period considered are reported in Table 1.

The dataset used in the regressions is composed of 3113 firm-year observations, most of which are from the United States (1322), followed at a distance by Japan (444), United Kingdom (214) and Canada (183).

In our analysis, we split up the twelve-year period considered in three homogeneous four-year sub-periods (2006-2009; 2010-2013; 2014-2017) to accommodate for the ESG scores' stickiness, especially in the early part of the timeframe.

Within the financial industry, we considered both banks (55\% of the sample) and non-bank financial firms (i.e., asset management, trading companies, financial products distributors, diversified financial services and consumer finance companies).

We resorted to multiple data sources to create our dataset. Our dependent variable, the CSP, is measured by MSCI ESG scores. These ratings range on a scale from one to ten and comprise environmental, social and governance factors; moreover, when combined in the overall ESG score, each pillar is weighted according to industry-specific characteristics of the rated issuer (see Table A2 in the Appendix A for further details). Table 2 provides the descriptive statistics of the ESG score and its three pillars over the period considered. 
Table 1. Sample constituents by country and year.

\begin{tabular}{|c|c|c|c|c|c|c|c|c|c|c|c|c|c|}
\hline \multirow{2}{*}{ Country } & \multicolumn{12}{|c|}{ Year } & \multirow{2}{*}{ TOT } \\
\hline & 2006 & 2007 & 2008 & 2009 & 2010 & 2011 & 2012 & 2013 & 2014 & 2015 & 2016 & 2017 & \\
\hline Austria & 2 & 2 & 2 & 2 & 2 & 2 & 2 & 2 & 2 & 2 & 2 & 2 & 24 \\
\hline Australia & 8 & 11 & 10 & 9 & 8 & 8 & 7 & 9 & 15 & 15 & 18 & 17 & 135 \\
\hline Belgium & 3 & 3 & 1 & 1 & 1 & 1 & 2 & 3 & 3 & 5 & 7 & 7 & 37 \\
\hline Canada & 6 & 11 & 7 & 8 & 8 & 7 & 8 & 16 & 23 & 27 & 30 & 32 & 183 \\
\hline Switzerland & 2 & 3 & 2 & 2 & 2 & & 2 & 1 & 6 & 15 & 17 & 1 & 53 \\
\hline Germany & 3 & 5 & 4 & 3 & 3 & 3 & 3 & 6 & 6 & 1 & 13 & 11 & 61 \\
\hline Denmark & 2 & 2 & 2 & 1 & 1 & 1 & 1 & 3 & 5 & 5 & 5 & 5 & 33 \\
\hline Spain & 7 & 6 & 5 & 7 & 7 & 6 & 5 & 7 & 7 & 8 & 9 & 9 & 83 \\
\hline Finland & & & & 1 & 1 & 1 & 1 & 1 & 1 & 2 & 2 & 2 & 12 \\
\hline France & 4 & 5 & 4 & 4 & 4 & 5 & 6 & 11 & 8 & 14 & 14 & 13 & 92 \\
\hline United Kingdom & 10 & 22 & 13 & 12 & 14 & 12 & 12 & 14 & 2 & 28 & 35 & 40 & 214 \\
\hline Hong Kong & 5 & 5 & 3 & 4 & 5 & 6 & 8 & 9 & 8 & 8 & 8 & 11 & 80 \\
\hline Italy & 7 & 8 & 7 & 4 & 4 & 3 & 2 & 7 & 10 & 16 & 20 & 20 & 108 \\
\hline Japan & 20 & 35 & 27 & 30 & 31 & 36 & 35 & 38 & 37 & 38 & 55 & 61 & 443 \\
\hline Netherlands & 2 & 2 & & & & & & 1 & 1 & 2 & 4 & 5 & 17 \\
\hline Norway & 2 & 2 & 2 & 1 & 1 & 1 & 1 & 1 & 4 & 5 & 6 & 7 & 33 \\
\hline Poland & & & & & & & & 12 & 12 & 9 & 8 & 8 & 49 \\
\hline Portugal & 2 & 2 & 2 & 1 & 1 & 1 & 1 & 1 & & 1 & 2 & 2 & 16 \\
\hline Sweden & 2 & 7 & 3 & 2 & 2 & 2 & 4 & & 9 & 10 & 14 & 17 & 72 \\
\hline Singapore & 4 & 4 & 4 & 4 & 4 & 4 & 4 & 4 & 4 & 4 & 5 & & 45 \\
\hline \multirow[t]{2}{*}{ United States } & 35 & 38 & 37 & 29 & 28 & 28 & 152 & 161 & 170 & 204 & 213 & 226 & 1321 \\
\hline & 126 & 173 & 135 & 125 & 127 & 127 & 256 & 307 & 333 & 419 & 487 & 496 & 3111 \\
\hline
\end{tabular}

This table shows the relative presence of financial firms in our final sample within each country by year, for a total of 3111 firm-year observations.

Table 2. ESG scores descriptive statistics.

\begin{tabular}{cccccc}
\hline & Mean & Median & Min & Max & SD \\
\hline 2006-2009 & & & & & \\
ESG & 4.51 & 4.29 & 0 & 10 & 2.39 \\
ENV & 4.65 & 4.67 & 0.19 & 9.85 & 1.70 \\
SOC & 5.07 & 5 & 0.9 & 9.78 & 1.59 \\
GOV & 4.95 & 4.83 & 1 & 9.77 & 1.61 \\
2010-2013 & & & & & \\
ESG & 4.61 & 4.2 & 0 & 10 & 2.09 \\
ENV & 4.02 & 4.2 & 0 & 10 & 1.99 \\
SOC & 4.70 & 4.8 & 0 & 10 & 1.62 \\
GOV & 5.71 & 5.7 & 0 & 10 & 2.03 \\
2014-2017 & & & & & \\
ESG & 4.58 & 4.4 & 0 & 10 & 1.99 \\
ENV & 4.21 & 3.9 & 0 & 10 & 2.65 \\
SOC & 4.21 & 4 & 0 & 10 & 1.45 \\
GOV & 5.79 & 5.9 & 0.2 & 10 & 1.72 \\
$2006-2017$ & & & & & \\
ESG & 4.58 & 4.3 & 0 & 10 & 2.08 \\
ENV & 4.22 & 4.25 & 0 & 10 & 2.39 \\
SOC & 4.45 & 4.3 & 0 & 10 & 1.55 \\
GOV & 5.66 & 5.7 & 0 & 10 & 1.85 \\
\hline
\end{tabular}

This table provides a summary of the mean, median, minimum, maximum and standard deviation values of the overall ESG scores and its three components (ENV, SOC and GOV) over the sample period 2006-2017 and the three sub-periods of interest.

The first two columns of Table 2 show the mean and the median values of the ESG score and its components. Overall, the average values range between 4.2 and 4.6, with exception of the governance pillar, whose values are significantly higher, particularly during the second and third quadrennium. The highest mean ESG score (4.79) was registered in 2014. Considering that these scores range on a scale from one to ten, the financial firms in our sample do not have particularly high CSP, even though some companies manage to reach the maximum score. 
The firm-specific variables are provided by Datastream. In our model, we control for financial firms' size, riskiness, capitalization and financial performance proxied by the variables' total asset, leverage, common equity and ROE respectively (see Table A1 in the Appendix A for the variables' definition). The firm-specific variables are winsorized at the 1st and 99th percentiles to reduce the effect of outliers.

The country-specific variables are provided by World Bank National Accounts data and OECD National Accounts data files. We look at the legal framework of the countries in our sample; to do so, we create the dummy variable civil law, which takes the value of 1 if the country has a civil law legal system and zero otherwise. We then take into account the degree of economic and social development, resorting to the variables of GDP growth and urban population (see Table A1 in the Appendix for further details).

Table 3 shows the descriptive statistics of the explanatory variables included in all our model specifications, whereas Table 4 displays the correlations between them and with the dependent variable.

Table 3. Explanatory variables' descriptive statistics.

\begin{tabular}{|c|c|c|c|c|c|c|c|}
\hline & Size & Leverage & Common Equity & ROE & Civil Law & GDP Growth & Urban Population \\
\hline Mean & 171 & $220 \%$ & $23.54 \%$ & $9.89 \%$ & 0.355 & $1.81 \%$ & $0.86 \%$ \\
\hline Median & 17.6 & $119 \%$ & $11.69 \%$ & $9.36 \%$ & 0 & $2 \%$ & $0.95 \%$ \\
\hline Min & 0.56 & $2 \%$ & $3.12 \%$ & $-65.28 \%$ & 0 & $-8.27 \%$ & $-1.60 \%$ \\
\hline $\operatorname{Max}$ & 2150 & $937 \%$ & $83.38 \%$ & $69.67 \%$ & 1 & $14.52 \%$ & $5.32 \%$ \\
\hline $\mathrm{Sd}$ & 419 & 244 & 23.89 & 12.43 & 0.48 & 1.58 & 0.49 \\
\hline $\mathrm{N}$ & 3111 & 3111 & 3111 & 3111 & 3111 & 3111 & 3111 \\
\hline
\end{tabular}

This table provides a summary of the mean, median, minimum, maximum and standard deviation values of the explanatory variables over the sample period 2006-2017, where SIZE is the total assets expressed in billions of US dollars, LEVERAGE is the ratio between total debt over common equity, COMMON EQUITY is the ratio between CET1 and total assets, ROE is the net income over common equity; see Table A1 in the Appendix for detailed definitions of all variables.

Table 4. Correlation among explanatory variables.

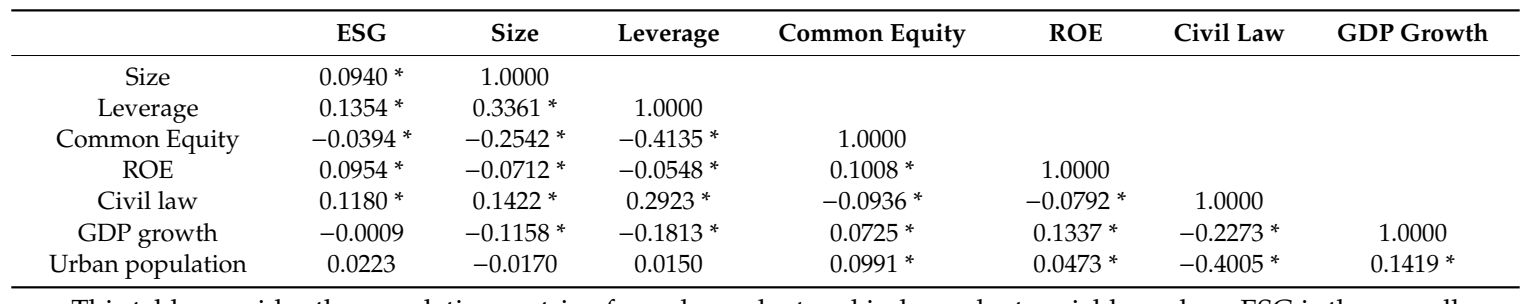

This table provides the correlation matrix of our dependent and independent variables, where ESG is the overall CSP score, SIZE is the natural logarithm of total assets, LEVERAGE is the ratio between total debt over common equity, COMMON EQUITY is the ratio between CET1 and total assets, ROE is the net income over common equity; see Table A1 in the Appendix for detailed definitions of all variables. Significance codes: ${ }^{*} p<0.05$.

The average financial firm in our sample has a total asset of almost $\$ 17$ billion and a $220 \%$ leverage rate; despite the fact that we winsorized the variable, the values of the leverage span from a minimum of $2 \%$ to a maximum of $937 \%$, which is not surprising, as there are both banks and non-bank financial firms in our sample. The medium ROE is around $10 \%$, again with great variability.

Six nations (Australia, Canada, Hong Kong, Singapore, United Kingdom and United States) out of the twenty-two included in the dataset are common law countries and, as expected from a sample of developed countries, the average GDP growth is rather low.

Table 4 provides Pearson correlation coefficients between all variables. The results show significant correlation between the ESG scores and both firm- and country-level variables. Regarding firm-level variables, the table shows a positive correlation between total assets, leverage, profitability and CSP, in line with the extant literature [7,36]. Interestingly, the correlation between ESG scores and Common Equity is negative and significant, but we devote more attention to this result and its implications in the results discussion (see paragraph 5). As for country variables, higher ESG scores seem to be associated with civil law countries. 
Since the descriptive statistics are derived from univariate analyses, we perform a multivariate analysis in the following section to provide empirical evidence to our hypotheses.

In order to answer our research questions, we proceed with a quantitative analysis; in particular, we posit that, within the financial industry, CSP is a function of firm, country and temporal determinants. To provide empirical evidence, we estimate the following regression model:

$$
\begin{gathered}
E S G_{i c t}=\alpha_{0}+\beta_{1} \text { FirmVariables }_{i t-1}+\beta_{2} \text { Country Variables }_{c t-1} \\
+\beta_{3} \text { TemporalVariables }+\varepsilon_{i t}
\end{gathered}
$$

The ESG score of firm $i$ in country $c$ at time $t$, is linearly affected by a set of firm- and country-specific variables. Furthermore, we posit that, over and above firm and country factors, ESG scores are also exposed to a positive trend, which is captured by different temporal variables. We also conducted a Cuzick test [37] for trends in these variables (see Table 5); the Cuzick test is a non-parametric test for trends across ordered groups.

Table 5. Baseline model.

\begin{tabular}{cccc}
\hline & $\mathbf{( 1 )}$ & $\mathbf{( 2 )}$ & $\mathbf{( 3 )}$ \\
\hline Size & $0.166^{* * *}$ & $0.257^{* * *}$ & $0.256^{* * *}$ \\
Leverage & $(0.025)$ & $(0.026)$ & $(0.026)$ \\
& $-0.003^{* * *}$ & -0.001 & -0.000 \\
Common Equity & $(0.000)$ & $(0.000)$ & $(0.000)$ \\
& $0.004^{*}$ & $0.010^{* * *}$ & $0.010^{* * *}$ \\
ROE & $(0.002)$ & $(0.002)$ & $(0.002)$ \\
& $0.013^{* * *}$ & $0.021^{* * *}$ & $0.021^{* * *}$ \\
Civil law & $(0.003)$ & $(0.003)$ & $(0.003)$ \\
& & $0.386^{* * *}$ & $0.408^{* * *}$ \\
GDP growth & & $(0.096)$ & $(0.096)$ \\
& & $-0.073^{* *}$ & -0.003 \\
Urban Population & & $(0.030)$ & $(0.233)$ \\
& & $0.340^{* * *}$ & $0.275^{* * *}$ \\
2010-2013 & & $(0.102)$ & $(0.099)$ \\
& & & $0.534^{* * *}$ \\
2014-2017 & & & $(0.676)$ \\
Country FE & & & $0.677^{* * *}$ \\
Year FE & Yes & No & No \\
Obs. & Yes & Yes & No \\
VIF test & 3111 & 3111 & 3111 \\
Cuzick test for trends & & & $\mathrm{z}=1.16^{* * * *}$ \\
& Yes & Yes & Yes \\
\hline
\end{tabular}

Table 5 shows the result of the OLS regression analysis on the relationship between ESG scores of three sets of lagged firm-, country- and time- specific factors added to the regression one at a time. Column 1 reports the coefficients of the firms' size (Total Assets), Leverage (total debt over common equity), Common equity (Common equity Tier 1 over total assets) and ROE (Net income/common equity) and includes country and time fixed effects. Column 2 adds the country-specific variable Civil Law, GDP growth and Urban Population (see Table A1 in the Appendix for the detailed definitions) and year fixed effects, whereas Column 3 adds the dummy variables controlling for the three quadrennia considered. The standard errors in parentheses are robust to heteroskedasticity. Significance codes: ${ }^{* *} p<0.01,{ }^{* *} p<0.05,{ }^{*} p<0.1$.

The baseline model presented in Table 5, takes the following specification:

$$
\begin{aligned}
\text { ESG }_{i c t}=\alpha_{0} & +\beta_{1} \text { TotalAssets }_{i t-1}+\beta_{2} \text { Leverage }_{i t-1}+\beta_{3} \text { CommonEquity }_{i t-1} \\
& +\beta_{4} \text { ROE }_{i t-1}+\beta_{5} \text { LegalFramework }_{c t-1}+\beta_{6} \text { GDPGrowth }_{c t-1} \\
& +\beta_{7} \text { UrbanPopulation }_{c t-1}+\beta_{8} 2010-2013+\beta_{9} 2014-2017 \\
& +\varepsilon_{i t}
\end{aligned}
$$


In the baseline model (see Table 5), we gradually include the three buckets of explanatory variables together with country and year fixed effect, as suggested by the Hausman test results. Firm and country factors have been lagged by one period to partially address problems that might exist due to potential endogeneity. We check for multicollinearity using the variance inflation factor (VIF) [38]. All errors are robust to heteroskedasticity. The variables' detailed definitions, sources and expected signs are reported in Table A1 in the Appendix.

We then performed a series of robustness checks (see paragraph 4.1); we first focus on the three typologies of explanatory variables included in the baseline model (firm, country, and temporal variables). In Table 6, we focus on firm-specific features and we report three sensitivity analyses: We divide the sample according to size and then between banks and non-bank financial firms. We further investigate within the sub-sample of banks whether a bank's specialization (proxied by the net interest income margin) may alter the influence of the explanatory variables on the CSP.

Table 6. Robustness checks: firm-level.

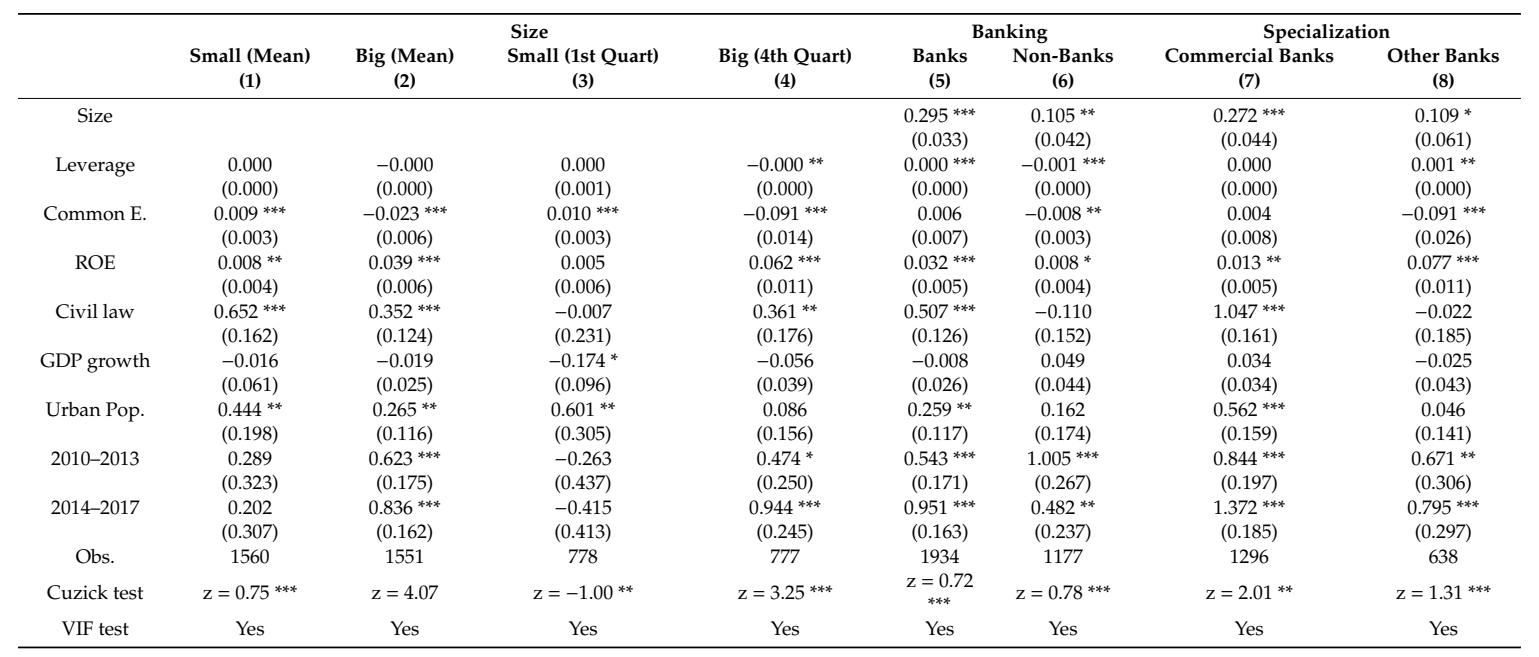

This table reports the estimate of the baseline model by size (below and above the mean total assets in columns 1 and 2 and in the bottom and top quartile of the total assets distribution in columns 3 and 4). Columns 5 and 6 report the estimate for banks and other financial firms respectively and columns 7 and 8 compare the results for banks with low and high reliance on interest revenues. The standard errors in parentheses are robust to heteroskedasticity. Significance codes: ${ }^{* * *} p<0.01,{ }^{* *} p<0.05,{ }^{*} p<0.1$.

Table 7 of the robustness checks is a sensitivity analysis at the country-level. We exclude the USA from the analysis, as it is over-represented in our sample and then we also run a regression specifically on this country. We then split the sample between countries with common law and civil law legal systems to analyze in a more straightforward way the impact of the legal framework on financial firms' ESG scores and finally, we compare the top and the bottom quartile of the GDP growth distribution, to neatly disentangle the effect of the economic development of a country.

We reflect on the temporal trend in the sensitivity analyses provided in Table 8 , by including the categorical variable year instead of the three sub-periods and we conduct further analyses using a dummy variable that controls for both the financial and the sovereign debt crises.

As for the robustness checks on the model, in order to alleviate any reverse causality problem, we exploit the dynamic nature of our panel by employing different temporal lags for the independent variables. We lag, by one year, the explanatory variables in the baseline model, whereas we use two-year-lagged variables and contemporary variables in the robustness tests presented in Table 9, panel A, columns 2 and 1 respectively. We also split into quartiles the ESG score distribution and added an order probit model to the analysis (see Table 9, panel A, column 3). Furthermore, to draw stronger causal inferences between CSP and firm-level variables, we assess the Granger causality link between the firm-specific variables and the ESG scores. In particular, we adopt the procedure proposed by Dumitrescu and Hurlin [39] for testing Granger causality in panel dataset. In order to overcome a 
potential sensitivity of the results to the number of lags included in the model, we select the number of lags that minimize the Akaike Information Criterion; the test points to one lag as the optimal choice. The results of the causality test are reported in Table 9, panel B.

Finally, as a further analysis, we shift our attention to the dependent variable and consider each pillar of the ESG score individually, to see whether and to what extent the set of explanatory variables used in the baseline model has a homogeneous influence on the environmental, social and government factors (see Table 10).

Table 7. Robustness checks: country-level.

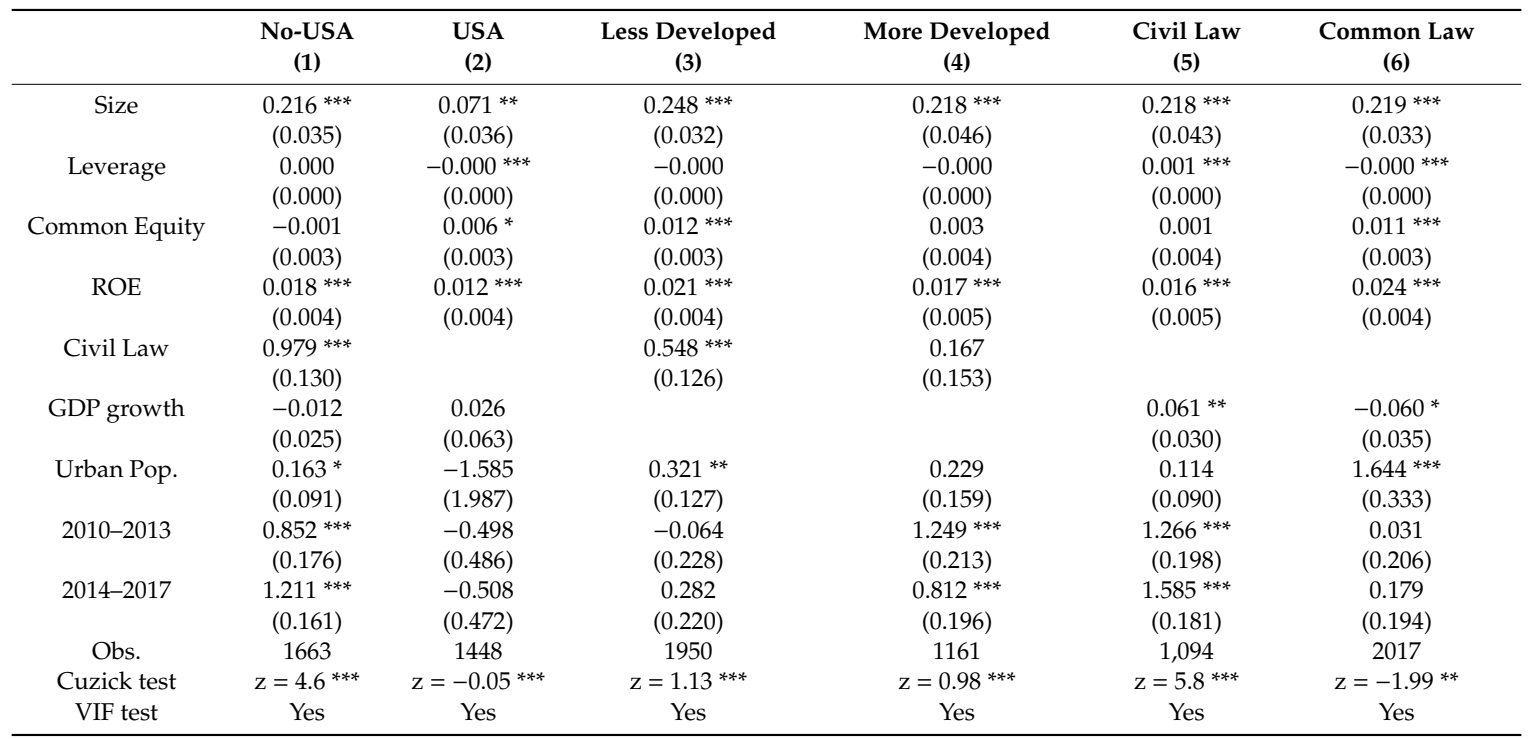

This table reports the estimate of the baseline model analyzing the influence of the United States on the overall results (columns 1,2), the impact of the economic development of the countries considered (columns 3,4) and the impact of the legal framework (columns 5,6). The standard errors in parentheses are robust to heteroskedasticity. Significance codes: ${ }^{* *} p<0.01,{ }^{* *} p<0.05,{ }^{*} p<0.1$.

Table 8. Robustness checks: temporal-level.

\begin{tabular}{cccc}
\hline & $\begin{array}{c}\text { Year } \\
\mathbf{( 1 )}\end{array}$ & $\begin{array}{c}\text { No-crises } \\
\mathbf{( 2 )}\end{array}$ & $\begin{array}{c}\text { Crises } \\
\mathbf{( 3 )}\end{array}$ \\
\hline Size & $0.254^{* * *}$ & $0.236^{* * *}$ & $0.229^{* *}$ \\
& $(0.026)$ & $(0.027)$ & $(0.090)$ \\
Leverage & -0.000 & -0.000 & -0.000 \\
& $(0.000)$ & $(0.000)$ & $(0.000)$ \\
Common Equity & $0.010^{* * *}$ & $0.009^{* * *}$ & -0.000 \\
& $(0.002)$ & $(0.003)$ & $(0.011)$ \\
ROE & $0.021^{* * *}$ & $0.015^{* * *}$ & $0.024^{* * *}$ \\
& $(0.003)$ & $(0.004)$ & $(0.007)$ \\
Civil Law & $0.372^{* * *}$ & $0.701^{* * *}$ & $-0.700^{* * *}$ \\
& $(0.096)$ & $(0.106)$ & $(0.230)$ \\
GDP growth & -0.015 & $-0.049^{*}$ & -0.006 \\
& $(0.022)$ & $(0.029)$ & $(0.032)$ \\
Urban Pop. & $0.240^{* *}$ & $0.508^{* * *}$ & -0.110 \\
& $(0.100)$ & $(0.105)$ & $(0.171)$ \\
Year & $0.058^{* * *}$ & & \\
& $(0.015)$ & & 481 \\
Obs. & 3111 & 2630 & 2.63 \\
Cuzick test & $1.16^{* * *}$ & $1.23^{* * *}$ & Yes \\
VIF test & Yes & Yes &
\end{tabular}

This table reports the sensitivity analysis on temporal factors. Column 1 displays the categorical variable year, instead of the two dummy variables representing one quadrennium each, whereas columns 2 and 3 assess the impact of the financial turmoil due to the global financial crisis (2008-2009) and sovereign debt crisis (2010-2011). The standard errors in parentheses are robust to heteroskedasticity. Significance codes: ${ }^{* *} p<0.01,{ }^{* *} p<0.05$, * $p<0.1$. 
Table 9. Robustness checks: model.

\begin{tabular}{|c|c|c|c|}
\hline Panel A & $\begin{array}{l}\text { Contemporaneous } \\
\text { (1) }\end{array}$ & $\begin{array}{c}\text { Double-Lag } \\
\text { (2) }\end{array}$ & $\begin{array}{c}\text { Ordered-Probit } \\
\text { (3) }\end{array}$ \\
\hline Size & $\begin{array}{c}0.247^{* * *} \\
(0.026)\end{array}$ & $\begin{array}{c}0.251^{* * *} \\
(0.026)\end{array}$ & $\begin{array}{c}0.045^{* * *} \\
(0.000)\end{array}$ \\
\hline Leverage & $\begin{array}{c}0.000 \\
(0.000)\end{array}$ & $\begin{array}{l}-0.000 \\
(0.000)\end{array}$ & $\begin{array}{c}0.000 \\
(0.170)\end{array}$ \\
\hline Common Equity & $\begin{array}{c}0.009^{* * *} \\
(0.002)\end{array}$ & $\begin{array}{l}0.011^{* * *} \\
(0.002)\end{array}$ & $\begin{array}{l}0.002^{* * *} \\
(0.000)\end{array}$ \\
\hline ROE & $\begin{array}{c}0.020^{* * *} \\
(0.003)\end{array}$ & $\begin{array}{c}0.023^{* * *} \\
(0.003)\end{array}$ & $\begin{array}{c}0.003^{* * *} \\
(0.000)\end{array}$ \\
\hline Civil law & $\begin{array}{c}0.440 * * * \\
(0.099)\end{array}$ & $\begin{array}{c}0.353^{* * *} \\
(0.099)\end{array}$ & $\begin{array}{c}0.081^{* * *} \\
(0.015)\end{array}$ \\
\hline GDP growth & $\begin{array}{c}-0.015^{* * *} \\
(0.000)\end{array}$ & $\begin{array}{c}-0.001 * * * \\
(0.000)\end{array}$ & $\begin{array}{c}0.001 \\
(0.033)\end{array}$ \\
\hline Urban Pop. & $\begin{array}{c}0.415^{* * *} \\
(0.104)\end{array}$ & $\begin{array}{c}0.251 \text { *** } \\
(0.093)\end{array}$ & $\begin{array}{c}0.044^{* * *} \\
(0.016)\end{array}$ \\
\hline 2010-2013 & $\begin{array}{c}0.515^{* * *} \\
(0.156)\end{array}$ & $\begin{array}{c}0.539 * * * \\
(0.178)\end{array}$ & $\begin{array}{c}0.087 * * * \\
(0.021)\end{array}$ \\
\hline 2014-2017 & $\begin{array}{c}0.645^{* * *} \\
(0.150)\end{array}$ & $\begin{array}{c}0.723^{* * *} \\
(0.170)\end{array}$ & $\begin{array}{c}0.129^{* * *} \\
(0.020)\end{array}$ \\
\hline Obs. & 3245 & 2924 & 3045 \\
\hline Cuzick test & $0.9^{* * *}$ & $1.57^{* * *}$ & $1.05^{* * *}$ \\
\hline VIF test & Yes & Yes & \\
\hline \multicolumn{4}{|l|}{ Panel B } \\
\hline \multicolumn{2}{|c|}{ Null hypotheses } & $\widetilde{Z}$ & $p$-value \\
\hline \multicolumn{2}{|c|}{ Tot. Assets does not granger cause ESG } & 3.1986 & 0.0016 \\
\hline \multicolumn{2}{|c|}{ ESG does not granger cause Tot. Assets } & -0.9164 & 0.3594 \\
\hline \multicolumn{2}{|c|}{ ROE does not granger cause ESG } & 3.2248 & 0.0013 \\
\hline \multicolumn{2}{|c|}{ ESG does not granger cause ROE } & 1.4829 & 0.1381 \\
\hline \multicolumn{2}{|c|}{ Common Equity does not granger cause ESG } & 3.8765 & 0.0001 \\
\hline \multicolumn{2}{|c|}{ ESG does not granger cause Common Equity } & 0.2911 & 0.7710 \\
\hline \multicolumn{2}{|c|}{ Leverage does not granger cause ESG } & 4.3846 & 0.0000 \\
\hline \multicolumn{2}{|c|}{ ESG does not granger cause Leverage } & 1.2801 & 0.2005 \\
\hline
\end{tabular}

This table shows the estimate of the robustness checks on the linear regression used in the baseline model. In panel A, column 1, the independent variables are not lagged, whereas in column 2, they have been lagged by two years compared to the ESG scores. Column 3 shows estimates of ordered probit models (marginal effects on conditional probabilities are reported). The standard errors in parentheses are robust to heteroskedasticity. Significance codes: ${ }^{* * *} p<0.01,{ }^{* *} p<0.05, * p<0.1$. Panel B addresses potential reverse-causality issues and reports the parameters of the Dumitrescu and Hurlin Granger test and their respective $p$-values.

Table 10. Environmental, social and governance pillars.

\begin{tabular}{cccc}
\hline & $\begin{array}{c}\text { ENV } \\
\mathbf{( 1 )}\end{array}$ & $\begin{array}{c}\text { SOC } \\
\mathbf{( 2 )}\end{array}$ & $\begin{array}{c}\text { GOV } \\
\mathbf{( 3 )}\end{array}$ \\
\hline Size & $0.446^{* * *}$ & $0.213^{* * *}$ & $-0.138^{* * *}$ \\
& $(0.026)$ & $(0.016)$ & $(0.023)$ \\
Leverage & $0.001^{* * *}$ & 0.000 & -0.000 \\
& $(0.000)$ & $(0.000)$ & $(0.000)$ \\
Common Equity & $0.057^{* * *}$ & $0.018^{* * *}$ & $-0.006^{* *}$ \\
& $(0.002)$ & $(0.002)$ & $(0.002)$ \\
ROE & $0.023^{* * *}$ & $0.007^{* * *}$ & $0.013^{* * *}$ \\
& $(0.004)$ & $(0.003)$ & $(0.003)$ \\
Civil law & -0.040 & $0.398^{* * *}$ & $-0.164^{* *}$ \\
& $(0.095)$ & $(0.066)$ & $(0.081)$ \\
GDP growth & $-0.107^{* * *}$ & $-0.036^{* * *}$ & $0.115^{* * *}$ \\
& $(0.019)$ & $(0.014)$ & $(0.017)$ \\
Urban Pop. & $0.186^{* * *}$ & 0.034 & $0.274^{* * *}$ \\
& $(0.091)$ & $(0.061)$ & $(0.084)$ \\
2010-2013 & -0.035 & -0.166 & $0.883^{* * *}$ \\
& $(0.121)$ & $(0.103)$ & $(0.112)$ \\
2014-2017 & 0.184 & $-0.475^{* * *}$ & $0.745^{* * *}$ \\
& $(0.122)$ & $(0.095)$ & $(0.098)$ \\
Obs. & 1311 & 1311 & 1311 \\
Cuzick test & $\mathrm{z}=-4.5$ & $\mathrm{z}=10.95$ & $\mathrm{z}=7.30^{* * *}$ \\
VIF test & Yes & Yes & Yes \\
\hline
\end{tabular}

This table shows the estimate of the baseline model run for each component of the overall ESG score, environmental (column 1), social (column 2) and government (column 3). The standard errors in parentheses are robust to heteroskedasticity. Significance codes: ${ }^{* * *} p<0.01,{ }^{* *} p<0.05, * p<0.1$. 


\section{Results}

Table 5 reports the estimation results for the regression model described in Equation (2), which investigates firm, country and temporal determinants of CSP within the financial industry.

The three buckets of independent variables (firm, country, and time factors) are gradually added to the model (see Table 5, columns 1 to 3).

The results reported in Table 5 provide evidence of the consistent effect of firm, country and temporal variables on the CSP within the financial industry. The sign, magnitude and significance of the variable size, confirms the widely shared findings e.g., $[1,18,33]$ that the higher the size of a firm, the higher its ESG score tends to be. The common equity and ROE have a strong, positive impact on financial firms' ESG scores, whereas the leverage presents its expected negative impact but loses significance in the full model specification. Overall, the first set of hypotheses cannot be rejected, with the exception of hypothesis $\mathrm{H} 1 \mathrm{~b}$ that can only be partially accepted.

To test the second set of hypotheses ( $\mathrm{H} 2 \mathrm{a}, \mathrm{H} 2 \mathrm{~b}$ and $\mathrm{H} 2 \mathrm{c})$, we include in the analysis three country-specific variables, which tend to have a homogeneous impact among all specifications (see columns 2 and 3). Having a civil law legal system appears to have a positive impact on the financial firms' CSP, as well as being in an economically developed country (the coefficient of GDP growth has a persistent negative sign but loses its significance in the last specification) with a growing urban population. In light of these empirical results, the second set of hypotheses cannot be rejected, with the exception of hypothesis $\mathrm{H} 2 \mathrm{~b}$ that can only be partially accepted.

Finally, the strong, positive and highly significant coefficients of the temporal trend variables indicate that time per se is an ESG determinant within the financial industry. Ceteris paribus, the two four-year terms spanning from 2010 to 2013 and from 2014 to 2017 have a strong positive effect on CSP compared to the quadrennium 2006-2009, and the latest period has an even stronger impact, compared to 2010-2013. This positive trend effect is also confirmed by the Cuzick test reported in column 3, therefore hypothesis $\mathrm{H} 3$ cannot be rejected.

\subsection{Robustness Checks}

To draw stronger causal inferences between CSP and firm, country and temporal factors, we carried out four sets of sensitivity tests.

We first focus at the firm-level and replicate our baseline model splitting the sample according to the size of the financial firms (Table 6, columns 1 to 4 ). In columns 1 and 2, financial firms are divided into two groups, below and above the average size, $\$ 171$ billion, whereas columns 3 shows the results for the financial firms in the bottom quartile of the size distribution (i.e., with total assets lower than $\$ 4.5$ billion) and column 4 considers the top quartile of the distribution, with financial firms with an average size above $\$ 627$ billion.

We then proceed to distinguish between banks and other financial firms (i.e., asset management, trading companies, financial products distributors, diversified financial services and consumer finance companies). Finally, we differentiate according to the reliance on interest income, within the banks' sub-sample (see columns 7 and 8).

The overall results are confirmed by the estimates reported in Table 6, with a few interesting exceptions. The relationship between common equity and CSP in big financial firms is negative. This might signal a practice well-known in the literature [40], according to which some institutions may include CSR practices in their management strategies or devote higher resources to them, particularly during hard financial times or while experiencing a phase of financial instability to increase their reputation and win over public approval. This result is common to banks with low net interest margin, for instance, private banks or investment banks.

Another result worth mentioning is related to the time trend, which is strong in most specifications, apart from particularly small financial firms. The financial firms that belong to the bottom quartile of the total assets' distribution (between \$56 million and \$4.52 billion), not only do not display an increasing tendency in their ESG scores but they present a statistically significant descending trend. 
Table 7 shows the sensitivity analyses performed at the country level. In the light of the over-representation of the United States in our sample, we exclude this country and replicate the analysis presented in the baseline model. The estimates reported in Table 7, column 1 ensure that the baseline model results are not driven by the United States. On the contrary, the regression performed on the American data alone provides evidence that this country has known a worrying negative trend of CSP in the financial industry (see Table 7 column 2); a similar conclusion is reached by Miralles-Quirós and co-authors [4]. This conclusion is supported both by the negative and statistically significant coefficients of the temporal factors and the Cuzick test performed. This result is so strong that it might be responsible for the lack of a positive trend observed in the analysis carried out on common law countries (see Table 7 column 6). In a departure from the extant literature (e.g., $\mathrm{Ng}$ [35]) the relative difference of the GDP growth, our proxy for economic development, do not seem to play a significant role in our analysis.

The estimates reported in Table 8 are primarily focused on checking the robustness of our results concerning the temporal factors. We therefore use the categorical variable year instead of the dummy variables controlling for time trends. The results in Table 8, column 1 provide empirical evidence that the temporal trends are not susceptible to different time controls.

We moreover investigate the role of financial turmoil on CSP determinants within the financial industry. To do so, we create a dichotomous variable crises, which control for both the global financial crisis (2008-2009) and the sovereign debt crisis (2010-2011). We decided to include both crisis periods, as twelve out of the twenty-two countries in our sample are European and they have been deeply affected by both crises. The crises periods significantly affect the antecedents that contribute to determine financial firms' CSP. In particular, during financial turmoil, firms' common equity ceases to play a role in the ESG scoring. When it comes to country-specific factors, the overall development of the countries has no role in increasing a financial firm's CSP and, while normally, civil law countries perform better in terms of ESG scores of the financial firms that operate within them, during financial turmoil, the relation changes sign, most possibly because common law nations have been less affected by the European sovereign debt crisis.

Finally, we perform a set of robustness checks on the model used for our main estimates. Table 9 reports the results of the baseline model with contemporaneous dependent and independent variables (see Table 9, panel A, column 1) and independent variables lagged by two years compared to the CSP (see Table 9, panel A, column 2). These columns show qualitatively the same results as the baseline model alleviating possible simultaneity problems. Moreover, we divide the ESG score distributions in quartiles and run an ordered probit regression, keeping the sets of control variables unchanged. This specification also gave fairly robust results compared to the baseline model estimates (see Table 9, panel A, column 3). Table 9, panel B reports the results of the Dumitrescu and Hurlin Granger test. By running the causality test, we find that the relationship between firm-specific variables and CSP is unidirectional, with total assets, ROE, Common Equity and Leverage Granger-causing the ESG scores and not vice versa. These findings contribute to reinforce our argument on the causal role played by the size, profitability, capitalization and riskiness of financial firms on their CSP.

\subsection{Further Analysis}

It is common among both scholars and practitioners to assess firms' corporate social performance by looking at an overall ESG index. In our analysis, we measure financial firms' CSP with MSCI ESG scores, which are derived from three underlying pillars: environmental, social and governance.

The environmental pillar (ENV) depends on carbon emissions and carbon footprint, as well as business vulnerability to climate change. It also assesses a company's efforts in sustaining the research of eco-friendly materials and procedures, and reflects how well a company uses best management practices to avoid environmental risks.

The social pillar (SOC) quantifies the sensitivity of a company towards human capital; more specifically, it entails the ability of a company to generate trust and loyalty within its stakeholders, 
to improve the quality of job conditions, to strengthen its reputation within the community and to safeguard human rights and safety.

Finally, the corporate governance factor (GOV) represents the ability of the management to apply the state-of-the-art corporate governance and corporate behavior standards. It focuses, in particular, on board diversification and gender pay gap, business ethics and overall transparency in order to create long-term value for the firm's shareholders.

Looking at the sub-factors that constitute each pillar (see Table A2 in the Appendix), it appears clear that each dimension has a very different nature. We therefore resort to the scores of the singular pillars to assess whether the determinants that affect the overall CSP have a homogeneous effect on each component, or, more reasonably, each area reacts to the determinants in a different way.

The focus of this paper is clearly on the overall CSP, because, on the one hand, it is the key reference in the literature and, on the other hand, it is the variable that drives most sustainable investment policies. It would be interesting to understand, though, the underlying mechanisms that drive the overall ESG sensitivity to firm, country and time factors, which may help in more awarely addressing social performance management.

The results in Table 10 suggest that the environmental and social pillars tend to drive the overall results, because they are positively influenced by the size of the financial firms, their capitalization and profitability. Analogously to the baseline model, financial firms tend to have higher CSP in economically and socially developed countries, as well. The result that stands out in Table 10, columns 1 and 2, however, is the lack of a positive trend, which consistently characterized the baseline model and most of the specifications tested in the robustness checks.

Column 3 of Table 10, though, draws even more the reader's attention, because it shows almost the opposite results, compared to the baseline model. According to the empirical evidence provided in Table 10, high governmental scores are associated with small financial firms with low common equity Tier 1 in least-developed countries. Moreover, the positive trend of this variable is so strong and persistent that it alone drives the growth of financial firms' overall CSP, that is commonly acknowledged by academic and grey literature (e.g., $[15,18])$ and that our analysis clearly highlights, as well. These peculiar results related to the governance component may be explained by the different rationale underlying this pillar compared to the other two, as explained in paragraph 5.

\section{Discussion}

The goal of this study is to explore the possible antecedents of CSP within the financial industry. We deepen our analysis by looking separately at the environmental, social and governance pillars to assess whether and to what extent the three different components are driven by the same firms' characteristics and whether they follow homogeneous patterns.

To do so, we firstly run some multivariate analyses, which confirm that over and above the firmand country-specific factors that enhance financial firms' CSP, the ESG scores of the firms in our sample follow a positive linear trend over time. Regarding firm-specific characteristics, this tendency is boosted by the financial firms' size and their profitability, which appear to exert a stable, positive influence on their CSP. With regards to size, our results mirror the overall findings of most of the existing literature, while the role of profitability is still controversial in previous research (e.g., [7,10,41]).

The size of a firm, in particular, is a key variable because the estimates show that the overall improvement in CSP is mainly driven by big financial firms, while small companies struggle to keep up with this growing tendency. Moreover, our findings provide evidence that particularly small financial firms, with total assets below $\$ 4.52$ billion, present a worrying descending trend in their overall ESG scores. These results may be due either to the shortage of financial and organizational resources to devote to internal and external sustainability practices on the part of small financial firms, or they may be driven by the visibility effect, as in Li et al. [42]. In addition, our findings seem to suggest that very big financial institutions (in the top quartile of our distribution, i.e., with an average total assets above $\$ 627$ billion) may be more likely to use positive ESG scores to deflect attention 
from non-optimal capital structures; this phenomenon is particularly evident in non-bank financial institutions and non-commercial banks (i.e., investment banks, private banks, etc.), which present an inverse relationship between the level of Common Equity and their CSP. In accordance to the legitimacy theory, this phenomenon, well-known in the extant literature (e.g., Dell'Atti et al. [43]), could be interpreted as an extreme instrumentalization of the positive effect exerted by CSP on companies' visibility, reputation and corporate image.

Backed by the institutional theory, we assume that organizations are also influenced by broader social structures, so we assess the impact of country-specific characteristics on the CSP of the financial firms that operate within them. Nations with civil law legal systems appear to be more attentive to sustainability within the financial industry, with the exception of the period comprised between the global financial crisis and the European sovereign debt crisis. This testifies that even in countries typically characterized by more rigid disclosure schemes, the prevailing attention to stakeholder value creation nudges them to embrace the current trend towards more sustainable businesses and to voluntarily disclose their CSPs. This finding seems to be specific to the financial industry, because previous cross-industry studies tend to associate common law legal frameworks with better CPS (e.g., Liang and Renneboog [44]). More specifically, the empirical results suggest that American financial firms seem to drive the negative correlation between common law countries and CSP, as they present a steady countertrend in their ESG scores. The scarce sensibility of the United States with regard to several aspects of sustainability is not new in the literature (e.g., $[45,46])$; for instance, Amel-Zadeh and Serafeim [45] point out that a larger percentage of US investors than Europeans do not consider ethical responsibility or ESG information as material for investment decision making and that US investors are less likely to believe that ESG considerations are effective in changing companies' behavior. Looking specifically at banks, Miralles-Quirós et al. [4] provide evidence that ESG information and, in particular, the governance pillar, has no effect on shareholder value creation in the United States.

In a departure from the extant literature (e.g., $\mathrm{Ng}$ [35]), the relative difference of GDP growth, our proxy for economic development, does not seem to play a significant role in explaining financial firms' CSP. This result may be due to the fact that previous comparable studies solely focused on banks and that the countries included in our sample span from less to more developed countries, but we do not consider developing countries.

Finally, further novel findings emerge when we deepen our analysis by looking at the single pillars of ESG scores. These results provide strong evidence of the profoundly different natures of the environmental, social and governance dimensions. The only characteristics that have a homogeneous effect on the overall ESG scores and each pillar are the financial firms' profitability and the social development of the country they operate in.

Beyond that, the environmental and social pillars, on the one hand, and the governance pillar on the other, seem to follow opposite trends and rationales. Big companies seem to primarily focus on environmental and social strategies to increase their CSP, whereas small financial firms particularly focus their efforts on the quality of their governance. This peculiar result may be explained by the different rationale underlying the governance pillar compared to the other two. Improving the governance score does not necessarily require monetary outlays, and this may help understanding the reason why small, less capitalized financial firms located in countries that still have margins of economic growth focus on this pillar to increase their overall CSP.

As a matter of fact, the financial industry's attention devoted to the governance pillar over time is growing so consistently that it appears to be driving alone the overall positive trend that has characterized financial firms' CSP within the latest decade, even after controlling for the firms' size.

\section{Conclusions}

This paper sets out to explore the effect of firm, country and time factors on financial firms' corporate social performance. We conjecture that the antecedent of CPS in the financial industry may differ from the prevailing results in the extant literature, which mainly focus on cross-industry studies. 
For our empirical analysis, we employ panel data models with lagged explanatory variables alongside a set of thorough robustness checks on the three buckets of explanatory variables and on the empirical model adopted. We furthermore alleviate possible reverse-causality concerns, ensuring that the relationships found in the baseline model are unidirectional.

The findings presented in this study reflect relevant contributions to the strategic management and social issues literatures; firstly, to the best of our knowledge, this is the first paper to explore the possible CSP antecedents within the financial industry by looking at a comprehensive framework that includes firm, country and temporal factors. Overall, our empirical findings suggest that big, solid and profitable financial firms are more likely to have high CSP, especially if they operate in a socially developed country with a civil law legal framework. Over and above the roles played by firm- and country-specific characteristics, we found a strong positive trend of the overall ESG scores across the whole financial industry. The effect of the factors identified may not be stable over time, especially during financial turmoil and may vary according to the financial firms' size, profitability and business model, as well as the economic and social development of the country they operate in. We, therefore, directly address such conjectures with specific robustness tests, which confirm the baseline results, with a couple of interesting exceptions: American financial firms and particularly small financial firms (i.e., with total assets between $\$ 56$ million and $\$ 4.52$ billion, belonging to the bottom quartile of the distribution) display a statistically significant descending trend in their corporate social performance, in stark contrast to the overall findings. Moreover, investment and private banks and non-bank financial institutions present an inverse relationship between the level of Common Equity and their CSP, suggesting that some institutions might resort to intensive CSR practices to deflect the markets and public attention from a non-optimal financial stability.

Furthermore, we disentangle the effect of such factors on the three single pillars comprised in the overall ESG score and find that the baseline model results are mainly driven by the environmental and social pillars, which, however, do not present an ascending trend. The governance pillar has a very strong positive trend, which seems to drive the overall increase in ESG scores over time, but reacts in a completely different, almost opposite way to firm and country factors, compared to the environmental and social pillars. Positive performance in the governance pillar is associated with small financial firms with low common equity Tier 1 in least-developed countries.

One of the main implications of our study is that ideally, regulators should consider the deeply different nature of the environmental, social and governance aspects and address them with ad hoc policies in order to improve homogeneously the overall CSP within the financial industry. Moreover, the different sets of incentives aimed at increasing financial firms' sustainability should somehow be sensitive to their size. On a more operative level, the different behaviors of the three ESG pillars, over time, have also direct implications on SRI strategies, which rarely differentiate among environmentally-, socially-, and governance-friendly issuers.

In our empirical analyses, we subdue any reverse causality concern, but we cannot exclude broader endogeneity issues due to unobservable firm or board characteristics and the possible self-reinforcing relationship between CSP and profitability. We, therefore, encourage other researchers to further address this limitation, resorting, for instance, to an IV approach or, ideally, to an experimental setting. Future research on the topic may also look more closely at the role of the board composition, management-specific heterogeneities or of banks' business models on their CPS.

The focus of this paper is clearly on the overall CSP, but it is interesting to understand the deeper mechanisms that drive the overall ESG sensitivity to firm, country and time factors. If we confine ourselves to solely considering the overall CSP, we may conclude that the forces that drive this variable within the financial industry are pretty predictable: big, profitable financial firms operating in rich countries have high CSP sounds very much like the same old story. Whereas, if we look more closely at the ESG scores' single components, we may narrate a different tale, because we are able to discover different frameworks that might provide both policy makers and practitioners with a more granular and effective set of tools to boost financial firms' CSP. 
Author Contributions: Conceptualization, F.C., M.M.; validation, C.F. and M.M.; formal analysis, M.M.; investigation, M.M.; methodology, M.M.; writing—original draft: F.C. and M.M.; writing—review and editing, F.C. and M.M. All authors have read and agreed to the published version of the manuscript.

Funding: This research received no external funding.

Conflicts of Interest: The authors declare no conflict of interest.

\section{Appendix A}

Table A1. Variables-definition, source and expected signs.

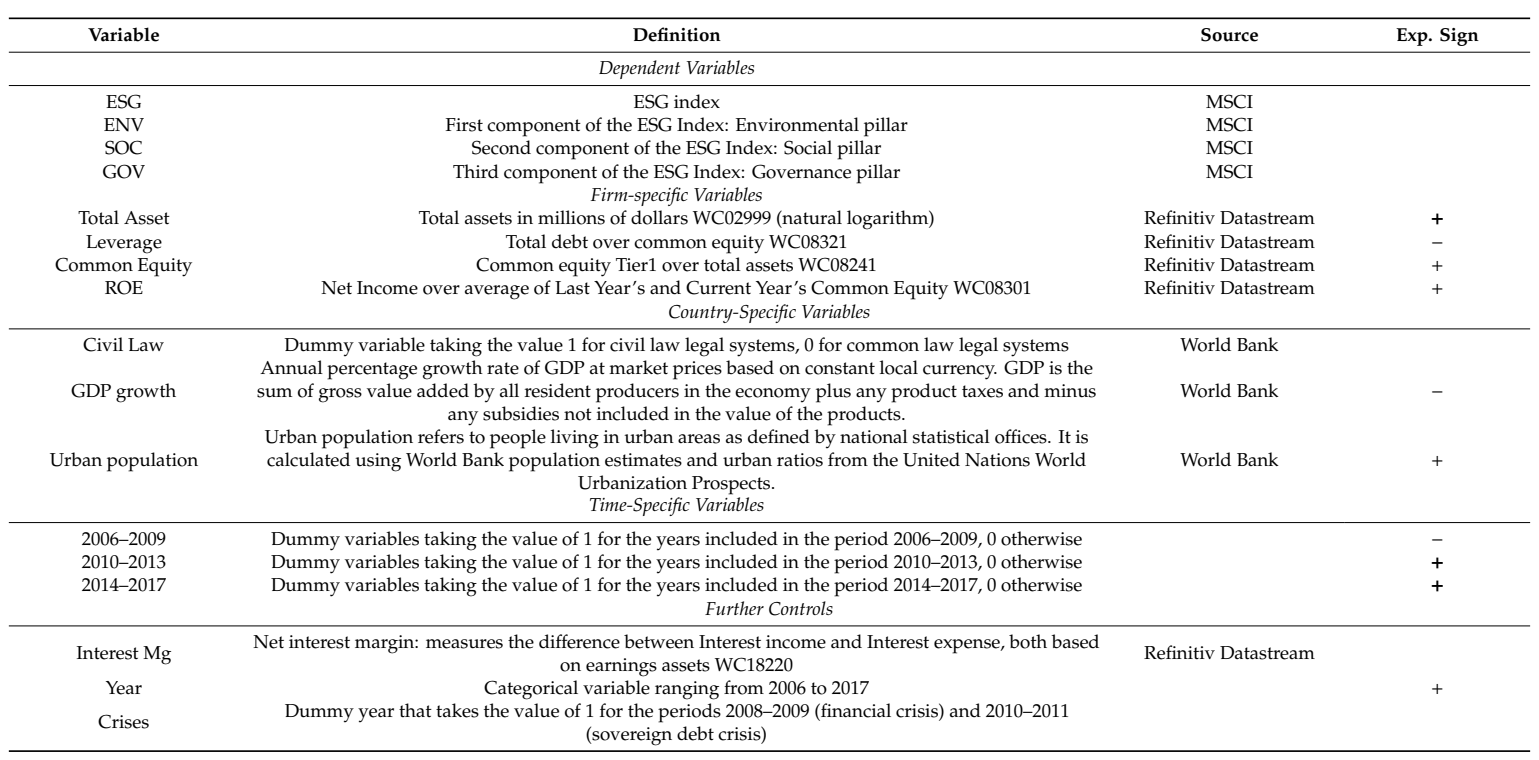

This table presents the economic meaning of the variables included in all model's specifications, their definitions, source and expected signs.

Table A2. MSCI ESG Research score scale.

\begin{tabular}{|c|c|c|c|}
\hline Pillars & Themes & \multicolumn{2}{|c|}{ Key Issue } \\
\hline \multirow{4}{*}{ Environment } & Climate change & $\begin{array}{c}\text { Carbon Emissions } \\
\text { Product carbon footprint }\end{array}$ & $\begin{array}{l}\text { Financing environmental impact } \\
\text { Climate change vulnerability }\end{array}$ \\
\hline & Natural resources & $\begin{array}{c}\text { Water stress } \\
\text { Biodiversity and land use }\end{array}$ & Raw material sourcing \\
\hline & Pollution and waste & $\begin{array}{c}\text { Toxic emission and waste } \\
\text { Packaging materials and waste }\end{array}$ & Electronic waste \\
\hline & Environmental opportunities & $\begin{array}{l}\text { Opportunities in clean tech } \\
\text { Opportunities in green building }\end{array}$ & Opportunities in renewable energy \\
\hline \multirow{4}{*}{ Social } & Human capital & $\begin{array}{l}\text { Labor management } \\
\text { Health and safety }\end{array}$ & $\begin{array}{l}\text { Human capital development } \\
\text { Supply chain labor standards }\end{array}$ \\
\hline & Product liability & $\begin{array}{l}\text { Product safety and quality } \\
\text { Chemical safety } \\
\text { Financial product safety }\end{array}$ & $\begin{array}{l}\text { Privacy and data security } \\
\text { Responsible investment } \\
\text { Heath and demography risk }\end{array}$ \\
\hline & Stakeholder opposition & Controversial sourcing & \\
\hline & Social opportunities & $\begin{array}{l}\text { Assess to communications } \\
\text { Access to finance }\end{array}$ & $\begin{array}{l}\text { Access to health care } \\
\text { Opportunities in nutrition and health }\end{array}$ \\
\hline \multirow[b]{2}{*}{ Governance } & Corporate governance & Board pay & $\begin{array}{l}\text { Ownership } \\
\text { Accounting }\end{array}$ \\
\hline & Corporate behavior & $\begin{array}{c}\text { Business ethics } \\
\text { Anti-competitive practices } \\
\text { Tax transparency }\end{array}$ & $\begin{array}{l}\text { Corruption and instability } \\
\text { Financial system instability }\end{array}$ \\
\hline
\end{tabular}

Source: MSCI ESG Research.

\section{References}

1. Ehrenhard, M.L.; Fiorito, T.L. Corporate values of the 25 largest European banks: Exploring the ambiguous link with corporate scandals. J. Public Aff. 2018, 18, e1700. [CrossRef]

2. Bennett, R.; Kottasz, R. Public attitudes towards the UK banking industry following the global financial crisis. Int. J. Bank Mark. 2012, 30, 128-147. [CrossRef] 
3. Escrig-Olmedo, E.; Fernandez-Izquierdo, M.A.; Ferrero-Ferrero, I.; Rivera-Lirio, J.; Munoz-Torres, M.J. Rating the Raters: Evaluating how ESG Rating Agencies Integrate Sustainability Principles. Sustainability 2019, 11, 915. [CrossRef]

4. Miralles-Quirós, M.M.; Miralles-Quirós, J.L.; Redondo Hernández, J. ESG Performance and shareholder value creation in the banking industry: International differences. Sustainability 2019, 11, 1404. [CrossRef]

5. Cash, D. Sustainable finance ratings as the latest symptom of 'rating addiction'. J. Sustain. Fin. Investig. 2018, 8, 242-258. [CrossRef]

6. Hossain, M.; Reaz, M. The determinants and characteristics of voluntary disclosure by Indian banking companies. Corp. Soc. Responsab. Environ. Manag. 2007, 14, 274-288. [CrossRef]

7. Khan, M.H.U.Z. The effect of corporate governance elements on corporate social responsibility (CSR) reporting: Empirical evidence from private commercial banks of Bangladesh. Int. J. Law Manag. 2010, 5, 82-109. [CrossRef]

8. Bhasin, M.L.; Makarov, R.R.; Orazalin, N.S. Determinants of Voluntary Disclosure in the Banking Sector: An Empirical Study. Int. J. Contemp. Bus. Stud. 2012, 3, 60-71.

9. Birindelli, G.; Dell'Atti, S.; Iannuzzi, A.P.; Savioli, M. Composition and Activity of the Board of Directors: Impact on ESG Performance in the Banking System. Sustainability 2018, 10, 4699. [CrossRef]

10. El-Halaby, S.; Hussainey, K. The Determinants of Social Accountability Disclosure: Evidence from Islamic Banks around the World. Int. J. Bus. 2015, 20, 203-223.

11. Paltrinieri, A.; Dreassi, A.; Migliavacca, M.; Piserà, S. Islamic finance development and banking ESG scores: Evidence from a cross-country analysis. Res. Int. Bus. Fin. 2020, 51, 101100.

12. Buallay, A. Is sustainability reporting (ESG) associated with performance? Evidence from the European banking sector. Manag. Environ. Qual. 2019, 30, 98-115. [CrossRef]

13. Shakil, M.H.; Mahmood, N.; Tasnia, M.; Munim, Z.H. Do environmental, social and governance performance affect the financial performance of banks? A cross-country study of emerging market banks. Manag. Environ. Qual. 2019, 30, 1331-1344. [CrossRef]

14. Campbell, J.L. Why would corporations behave in socially responsible ways? An institutional theory of corporate social responsibility. Acad. Manag. Rev. 2007, 32, 946-967. [CrossRef]

15. Baldini, M.; dal Maso, L.; Liberatore, G.; Mazzi, F. Role of Country- and Firm-Level Determinants in Environmental, Social, and Governance Disclosure. J. Bus. Ethics 2018, 150, 79-98. [CrossRef]

16. DiMaggio, P.J.; Powell, W.W. The iron cage revisited: Institutional isomorphism and collective rationality in organizational fields. Am. Soc. Rev. 1983, 48, 147-160. [CrossRef]

17. Doyle, M.T. Ratings That Don't Rate: The Subjective World of ESG Ratings Agencies; ACCF: Washington, DC, USA, 2018.

18. Short, J.C.; McKenny, A.F.; Ketchen, D.J.; Snow, C.C.; Hult, G.T. An empirical examination of firm, industry, and temporal effects on corporate social performance. Bus. Soc. 2016, 55, 1122-1156. [CrossRef]

19. Moura-Leite, R.C.; Padgett, R.C.; Galan, J.I. Is social responsibility driven by industry or firm-specific factors? Manag. Decis. 2012, 50, 1200-1221. [CrossRef]

20. Berg, F.; Koelbel, J.F.; Rigobon, R. Aggregate Confusion: The Divergence of ESG Ratings. 2019. Available online: https://papers.ssrn.com/sol3/papers.cfm?abstract_id=3438533 (accessed on 1 July 2020).

21. Ioannou, I.; Serafeim, G. "The Consequences of Mandatory Corporate Sustainability Reporting”. In The Oxford Handbook of Corporate Social Responsibility: Psychological and Organizational Perspectives; McWilliams, A., Rupp, D.E., Siegel, D.S., Stahl, G.K., Waldman, D.A., Eds.; Oxford University Press: Oxford, UK, 2019; pp. 485-489.

22. Gallicano, T.A. Critical Analysis of Greenwashing Claims. Public Relat. J. 2011, 5, 1-21.

23. Kim, E.-H.; Lyon, T.P. Greenwash vs. brownwash: Exaggeration and undue modesty in corporate sustainability disclosure. Organ. Sci. 2015, 26, 705-723. [CrossRef]

24. Elsakit, O.M.; Worthington, A.C. The impact of corporate characteristics and corporate governance on corporate social and environmental disclosure: A literature review. Int. J. Bus. Manag. 2014, 9, 1. [CrossRef]

25. Giannarakis, G. The determinants influencing the extent of CSR disclosure. J. Law Manag. 2014, 56, 393-416. [CrossRef]

26. Rahman, N.H.W.A.; Zain, M.M.; Al-Haj, N.H.Y.Y. CSR disclosures and its determinants: Evidence from Malaysian government link companies. Soc. Responab. J. 2011, 7, 181-201. 
27. Jennifer Ho, L.C.; Taylor, M.E. An empirical analysis of triple bottom-line reporting and its determinants: Evidence from the United States and Japan. J. Int. Fin. Manag. Acc. 2007, 18, 123-150. [CrossRef]

28. Haniffa, R.M.; Cooke, T.E. The impact of culture and corporate governance on corporate social reporting. J. Acc. Pub. Policy 2005, 24, 391-430. [CrossRef]

29. Reverte, C. Determinants of corporate social responsibility disclosure ratings by Spanish listed firms. J. Bus. Ethics 2009, 88, 351-366. [CrossRef]

30. Fatemi, A.; Glaum, M.; Kaiser, S. ESG performance and firm value: The moderating role of disclosure. Glob. Fin. J. 2017, 38, 45-64. [CrossRef]

31. Branco, M.; Rodrigues, L. Corporate social responsibility and resource-based perspectives. J. Bus. Ethics 2006, 69, 111-132. [CrossRef]

32. Malik, M. Value-Enhancing Capabilities of CSR: A Brief Review of Contemporary Literature. J. Bus. Ethics 2015, 127, 419-438. [CrossRef]

33. Margolis, J.D.; Elfenbein, H.A.; Walsh, J.P. Does it Pay to Be Good. . . and Does it Matter? A Meta-Analysis of the Relationship between Corporate Social and Financial Performance. 2009. Available online: https: //papers.ssrn.com/sol3/papers.cfm?abstract_id=1866371 (accessed on 1 July 2020).

34. Forte, L.M.; dos Santos Neto, J.B.; Nobre, F.C.; Nobre, L.H.; Queiroz, D.B. Determinants of Voluntary Disclosure: A Study in the Brazilian Banking Sector. Rev. Gest. Fin. Con. 2015, 5, 23-37. [CrossRef]

35. Ng, A. The Tangibility of the Intangibles: What Drives Banks' Sustainability Disclosure in the Emerging Economies? GEG: Oxford, UK, 2016; p. 120.

36. Tagesson, T.; Blank, V.; Broberg, P.; Collin, S.O. What explains the extent and content of social and environmental disclosures on corporate Web sites: A study of social and environmental reporting in Swedish listed corporations. Corp. Soc. Responsab. Environ. Manag. 2009, 16, 352-364. [CrossRef]

37. Cuzick, J. A Wilcoxon-type Test for Trend. Stat. Med. 1985, 4, 87-90. [CrossRef] [PubMed]

38. Hair, J.F., Jr.; Black, W.C.; Babin, B.J.; Anderson, R.E. Multivariate Data Analysis: A Global Perspective, 7th ed.; Prentice Hall: Upper Saddle River, NJ, USA, 1998.

39. Dumitrescu, E.-I.; Hurlin, C. Testing for Granger causality in heterogeneous panels. Econ. Model. 2012, 29, 1450-1460. [CrossRef]

40. Hemingway, C.A.; Maclagan, P.W. Managers' Personal Values as Drivers of Corporate Social Responsibility. J. Bus. Ethics 2004, 50, 1. [CrossRef]

41. Aras, G.; Aybars, A.; Kutlu Fortuna, O. Managing corporate performance: Investigating the relationship between corporate social responsibility and financial performance in emerging markets. Int. J. P Perf. Manag. 2010, 59, 229-254. [CrossRef]

42. Li, F.; Morris, T.; Young, B. The Effect of Corporate Visibility on Corporate Social Responsibility. Sustainability 2019, 11, 3698. [CrossRef]

43. Dell'Atti, S.; Trotta, A.; Iannuzzi, A.P.; Demaria, F. Corporate social responsibility engagement as a determinant of bank reputation: An empirical analysis. Corp. Soc. Responsab. Environ. Manag. 2017, 24, 589-605. [CrossRef]

44. Liang, H.; Renneboog, L. On the foundations of Corporate Social Responsibility. J. Fin. 2017, 72, 853-910. [CrossRef]

45. Amel-Zadeh, A.; Serafeim, G. Why and how investors use ESG information: Evidence from a global survey. Fin. Anal. J. 2018, 74, 87-103. [CrossRef]

46. Maignan, I.; Ralston, D.A. Corporate social responsibility in Europe and the US: Insights from businesses' self-presentations. J. Int. Bus. Stud. 2002, 33, 497-514. [CrossRef]

(C) 2020 by the authors. Licensee MDPI, Basel, Switzerland. This article is an open access article distributed under the terms and conditions of the Creative Commons Attribution (CC BY) license (http://creativecommons.org/licenses/by/4.0/). 